\title{
EFEK HIGH PASS FILTERING DENGAN KOEFESIEN NOL PADA CITRA BINER
}

\author{
Teady Matius Surya Mulyana ${ }^{1}$ \\ ${ }^{1}$ Program Studi Teknik Informatika, Universitas Bunda Mulia Jakarta \\ tmulyana@bundamulia.ac.id
}

\begin{abstract}
ABSTRAK
Filtering akan melakukan penapisan terhadap nilai tertentu. Nilai intensitas yang dimiliki oleh citra biner hanya mempunyai nilai 1 dan 0 . Filtering pada citra biner dengan menggunakan high pass filtering dengan total koefesien nol akan menghasilkan pemisahan piksel tepi dengan piksel objek yang tegas daripada filtering pada citra grayscale. Tujuan dilakukannya penelitian ini untuk mencermati efek high pass filtering dengan koefesien nol terhadap citra biner. Penelitian dilakukan dengan melakukan proses konvolusi terhadap citra yang dibinerkan terlebih dahulu. Variasi objek hitam dengan latar putih, maupun objek putih dengan latar hitam, jika dioperasikan dengan variasi kondisi core filter berupa nilai core positif maupun nilai core negatif akan sama-sama menghasilkan piksel tepi objek yang berwarna putih dan piksel yang bukan tepi objek baik pada latar maupun objek menjadi berwarna hitam. Hasil penelitian ini menghasilkan keberhasilan 100\% terhadap dugaan awal mengenai efek high pass filtering dengan koefesien nol terhadap citra biner. Dugaan awal tersebut adalah variasi efek tersebut menghasilkan tepi di bagian luar objek dan tepi di bagian dalam objek. Filter dengan core positif pada citra biner dengan objek hitam dan latar putih akan menghasilkan tepian dibagian luar dari objek. Hal yang sama terjadi pada filter dengan core negatif, pada citra biner dengan objek putih dengan latar hitam. Sedangkan Filter dengan core positif pada citra biner dengan objek putih dan latar hitam akan menghasilkan tepian di bagian dalam dari objek, demikian juga filter dengan core negatif, pada citra biner dengan objek hitam dengan latar putih.
\end{abstract}

Kata kunci: citra biner, high pass filtering, konvolusi

\section{PENDAHULUAN}

Filtering spasial linier merupakan filtering yang dilakukan dengan operasi linear berupa konvolusi atau korelasi antara area lokal suatu sel bitmap dengan kernel. Pada proses filtering diperlukan sebuah filter $\mathrm{g}(\mathrm{x}, \mathrm{y})$ berupa matriks berukuran $\mathrm{m} \times \mathrm{n}$, pada umumnya matriks yang digunakan adalah matriks berukuran $3 \times 3$ yang tiap-tiap sel-sel nya berisi nilai bobot. Matriks ini disebut sebagai filter, mask, atau kernel, ada juga yang menyebutnya window. Setiap titik (x,y) pada citra $\mathrm{f}(\mathrm{x}, \mathrm{y})$ di filter dengan filter $\mathrm{g}(\mathrm{x}, \mathrm{y})$ menghasilkan $\mathrm{h}(\mathrm{x}, \mathrm{y})$, (Roopashree, 2012).

Kernel High Pass Filtering adalah kernel untuk menapis nilai dengan intensitas yang tinggi serta menguranginya dengan nilai intensitas yang rendah, sehingga dapat menghasilkan efek penajaman citra (Makandar, 2015). Kernel dirancang untuk menambah kecerahan suatu piksel berdasarkan andil dari nilai-nilai tetangganya Khalefa (Khalefa, 2011).

Clausthal, (Clausthal, 2009) menjelaskan deteksi tepi ada yang mempunyai arah ada juga yang tidak mempunyai arah. Arah yang dimaksud disini adalah adanya nilai yang lebih tinggi atau lebih rendah pada suatu sisi dibandingkan dengan sisi yang lain. Kernel high pass filtering yang dipergunakan pada deteksi tepi ini adalah kernel high pass filtering yang tidak mempunyai arah, sehingga kernel ini dapat dioperasikan dengan korelasi saja.

Secara umum, kernel high pass filtering dengan pusat kernel yang bernilai positif ditujukan untuk menahan nilai dengan intensitas yang tinggi yang berbatasan dengan nilai dengan intensitas yang rendah, sehingga dapat mendeteksi tepi dari citra dengan objek yang cerah. Gambar 1 merupakan contoh-contoh kernel high pass filtering. 


$$
\begin{array}{lcc}
{\left[\begin{array}{ccc}
0 & 2 & 0 \\
2 & -8 & 2 \\
0 & 2 & 0
\end{array}\right]} & {\left[\begin{array}{ccc}
1 & 1 & 1 \\
1 & -8 & 1 \\
1 & 1 & 1
\end{array}\right]} \\
{\left[\begin{array}{ccc}
0 & -2 & 0 \\
-2 & 8 & -2 \\
0 & -2 & 0
\end{array}\right]} & {\left[\begin{array}{ccc}
-1 & -1 & -1 \\
-1 & 8 & -1 \\
-1 & -1 & -1
\end{array}\right]}
\end{array}
$$

Gambar 1. Kernel-kernel High Pass Filtering dengan Total Koeefesien Nol

Kernel high pass filtering dengan nilai koefesien nol mempunyai perbedaan sel pusat dengan tetangga-tetangganya yang sangat besar. Kernel ini mempunyai sel pusat yang mempunyai nilai tertingginya, sedangkan sel-sel tetangganya bernilai negatif.

Kernel high pass filtering dengan nilai koefesien nol dapat juga mempunyai nilai core negatif. Kernel ini mempunyai nilai pusat sel yang sangat rendah dengan nilai-nilai tetangganya positif. Perbedaan pusat kernel dengan tetangganya juga besar seperti kernel dengan core positif. Kernel ini akan memfilter piksel dengan nilai yang rendah dibanding dengan piksel-piksel tetangganya.

Proses filtering dilakukan dengan melakukan operasi konvolusi. Shareef, (Shareef, 2012) menggolongkan operator ini sebagai operator konvolusi dari Srivastava-Attiya yang merupakan hasil penjumlah secara rekursif dari fungsi-fungsi linear. Umar, (Umar, 2007) menjelaskan bahwa konvolusi pada keperluan proses optik, berguna dalam banyak hal untuk keperluan penajaman citra, maupun untuk proses penghalusan gradasi citra. Untuk keperluan pemrograman, proses ini dirumuskan sesuai dengan rumus (1) (Soetoyo, 2009).

$h(x, y)=f(x, y) \times g(x, y)=\sum_{k=1}^{M} \sum_{l=1}^{N} f(k, l) \cdot g(x-(k-m), y-(l-n))$

Keterangan:

- $\mathrm{x}, \mathrm{y}, \mathrm{k}, 1 \rightarrow$ variabel bebas yang memiliki nilai diskrit, dimana $\mathrm{x}$ dan y adalah koordinat piksel yang sedang diolah, $\mathrm{k}$ dan 1 adalah koordinat dari piksel dalam suatu area lokal yang memperngaruhi hasil $\mathrm{h}(\mathrm{x}, \mathrm{y})$

- $\mathrm{h}(\mathrm{x}, \mathrm{y})$ hasil pada koordinat $\mathrm{x}, \mathrm{y}$

- $\mathrm{f}(\mathrm{x}, \mathrm{y}) \rightarrow$ fungsi f yang mengolah piksel $\mathrm{x}, \mathrm{y}$ berikut tetangganya

- $\mathrm{g}(\mathrm{x}, \mathrm{y}) \rightarrow$ fungsi filter untuk mengolah piksel $\mathrm{x}, \mathrm{y}$

- $\mathrm{M}, \mathrm{N} \rightarrow$ batas titik tetangga yang mempengaruhi titik yang sedang diolah

Proses konvolusi pada bagian tepi citra akan memerlukan piksel tambahan diluar piksel-piksel bagian tepi citra. Piksel tambahan ini akan dikonvolusi atau dikorelasi dengan kernel ketika ketika core kernel berhimpit dengan bagian piksel pada bagian tepi citra. Mulyana, (Mulyana, 2017) pada penelitiannya, memberikan kebijakan nilai tepi dengan menggandakan nilai piksel paling tepi dari citra sebagai nilai dari tepian citra, dengan demikian piksel paling tepi citra akan dikonvolusi dengan sebagian dari dirinya sendiri yang merupakan nilai dari tepian citra. 


\section{METODE PENELITIAN}

\section{Dugaan Awal}

Penelitian dilakukan dengan mengambil dugaan awal yang didukung dengan aplikasi spreadsheet untuk memastikan nilai yang terjadi dari hasil konvolusi memang sesuai dengan yang diduga. Secara umum filter high pass filtering dengan koefesien nol yang memiliki core positif akan menapis piksel yang nilai intensitasnya rendah dengan piksel tetangga yang memiliki nilai intensitas yang tinggi, serta meloloskan piksel dengan nilai intensitas yang tinggi dengan piksel tetangga yang nilai intensitas nya rendah (Putra, 2010).

Berdasarkan filter high pass filtering dengan koefesien nol yang sudah ada, Mulyana juga merancang filter dengan core negatif. Hal kebalikan terjadi pada filter high pass filtering dengan koefesien nol yang memiliki core negatif akan menapis piksel yang nilai intensitasnya tinggi dengan piksel tetangga yang memiliki nilai intensitas yang rendah, serta meloloskan piksel dengan nilai intensitas yang rendah dengan piksel tetangga yang nilai intensitas nya tinggi (Mulyana, 2017).

Berdasarkan sifat dari high pass filtering dengan koefesien nol tersebut, maka disusun dugaan awal:

- Pada citra dengan objek hitam dan latar putih yang difilter dengan filter yang memiliki core positif akan menghasilkan tepian pada bagian luar dari objek.

- Pada citra dengan objek hitam dan latar putih yang difilter dengan filter yang memiliki core negatif akan menghasilkan tepian pada bagian alam dari objek.

- Pada citra dengan objek putih dan latar hitam yang difilter dengan filter yang memiliki core positif akan menghasilkan tepian pada bagian dalam dari objek.

- Pada citra dengan objek putih dan latar hitam yang difilter dengan filter yang memiliki core negatif akan menghasilkan tepian pada bagian dalam dari objek.

\section{Percobaan Menggunakan Aplikasi Spreadsheet}

Untuk mendukung proses pengujian agar diperoleh gambaran mengenai nilai yang dihasilkan dari proses filtering pada tiap selnya, dibuat aplikasi filtering menggunakan spreadsheet. Seperti yang ditunjukkan pada gambar 2 .

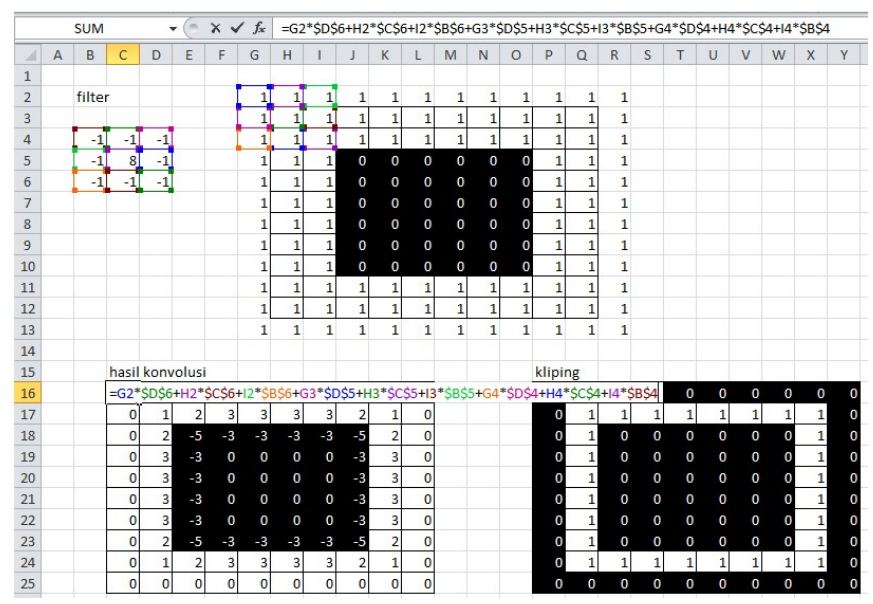

Gambar 2. Aplikasi Dengan Spreadsheet 
Untuk keperluan konvolusi pada spreadsheet ini, rumus (1) diterapkan pada excel sesuai dengan rumus spreadsheet yang tercantum formula, jika ditinjau dari sel pertama atau sel paling kiri atas atau sel C6.

Objek dibuat dengan nilai 0 atau 1 pada sel, serta dibuat rumus pada sel-sel konvolusi yang akan mengkonvolusikan sel filter pada sel B4 sampai sel D6 dengan sel citra pada sel H4 sampai sel Q12. Percobaan dilakukan dengan memberikan citra rekaan pada spreadsheet sesuai dengan kondisi yang diinginkan, yaitu citra dengan objek hitam dan latar putih serta citra dengan objek putih dengan latar hitam. Hasil percobaan ini mendukung semua dugaan awal.

Pada citra dengan objek hitam dan latar putih yang difilter dengan filter yang memiliki core positif akan menghasilkan tepian pada bagian luar dari objek. Hasil percobaan yang ditunjukkan pada pada gambar 3a memperlihatkan adanya peningkatan nilai intensitas piksel latar yang berbatasan dengan objek. Sedangkan semua piksel objek dan piksel latar yang tidak berbatasan dengan objek nilainya akan berisi mulai dari 0 sampai minus, Citra tepi yang dihasilkan berwarna hitam dengan latar putih.

Pada citra dengan objek hitam dan latar putih yang difilter dengan filter yang memiliki core negatif akan menghasilkan tepian pada bagian dalam dalam dari objek. Hasil percobaan yang ditunjukkan pada pada gambar 3.b memperlihatkan adanya peningkatan nilai intensitas piksel objek yang berbatasan dengan latar. Sedangkan semua piksel objek dan piksel latar yang tidak berbatasan dengan objek nilainya berisi 0 sampai minus. Citra tepi yang dihasilkan berwarna putih dengan latar hitam.

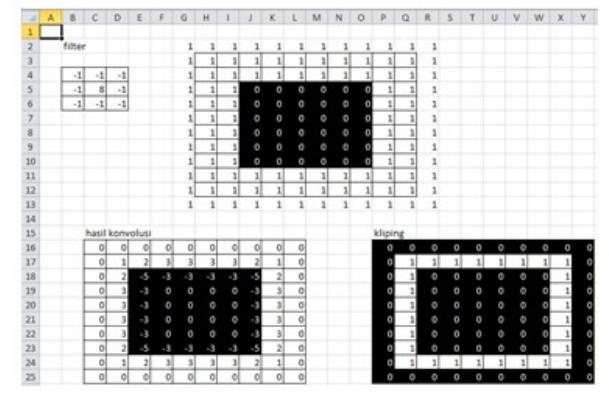

(a)

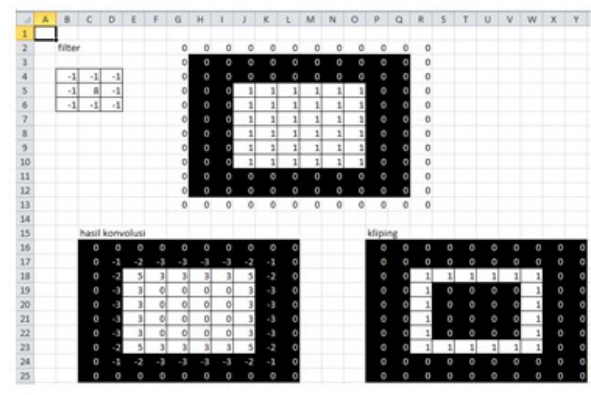

(c)

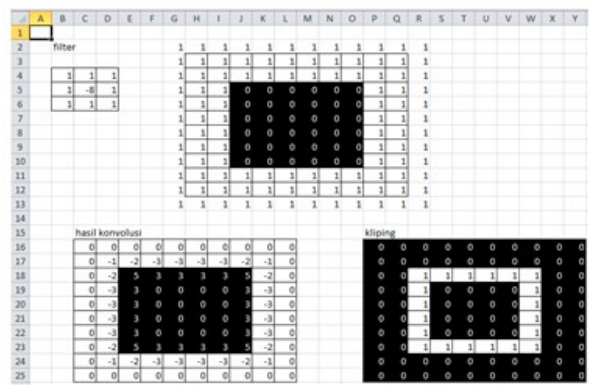

(b)

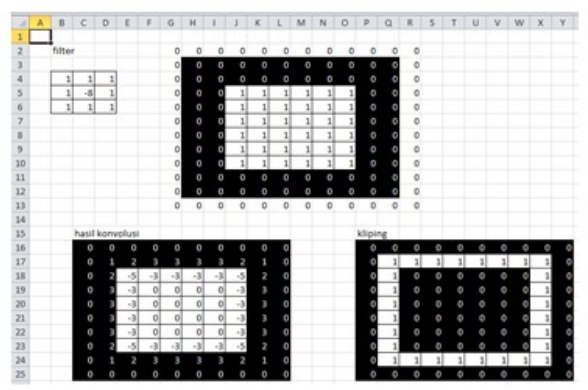

(d)

Gambar 3.a. Spreadsheet Objek Hitam Latar Putih Core Positif Gambar 3.b. Spreadsheet Objek Hitam Latar Putih Core Negatif Gambar 3.c. Spreadsheet Objek Putih Latar Hitam Core Positif Gambar 3.d. Spreadsheet Objek Putih Latar Hitam Core Negatif 
Pada citra dengan objek putih dan latar hitam yang difilter dengan filter yang memiliki core positif akan menghasilkan tepian pada bagian dalam dari objek. Hasil percobaan yang ditunjukkan pada pada gambar 3.c memperlihatkan adanya peningkatan nilai intensitas piksel objek yang berbatasan dengan latar. Sedangkan semua piksel objek dan piksel latar yang tidak berbatasan dengan objek nilainya akan berisi 0 sampai minus. Citra tepi yang dihasilkan berwarna putih dengan latar hitam. Efek yang dihasilkan seperti pada hasil nomor 2 di atas. Tetapi karena nilai objek yang berbatasan dengan tepi bernilai 1, maka peningkatan nilai objek tetap menghasilkan sel yang berwarna putih.

Pada citra dengan objek putih dan latar hitam yang difilter dengan filter yang memiliki core negatif akan menghasilkan tepian pada bagian dalam dari objek. Hasil percobaan yang ditunjukkan pada pada gambar 3.d memperlihatkan adanya peningkatan nilai intensitas piksel latar yang berbatasan dengan objek. Sedangkan semua piksel objek dan piksel latar yang tidak berbatasan dengan objek nilainya akan berisi 0 sampai minus. Citra tepi yang dihasilkan berwarna hitam dengan latar putih. Efek ini sama dengan efek hasil percobaan nomor 1 di atas.

\section{Program Untuk Membantu Menguji Dugaan Awal}

Untuk membantu menguji dugaan yang sudah ada, disusun program, dimana tampilan program dapat dilihat pada gambar 4. Program terdiri dari 6 panel gambar, yang terbagi pada dua baris. Panel pertama pada baris pertama merupakan citra asli, dengan warna RGB yang penuh. Panel kedua pada baris pertama merupakan citra grayscale, sedangkan panel ketiga pada baris pertama merupakan citra biner yang dihasilkan dari proses operasi ambang sesuai dengan nilai ambang yang diatur dari trackbar threshold.

Panel-panel gambar pada baris kedua terdiri dari panel pertama pada baris kedua yang merupakan hasil filter, panel kedua pada baris kedua merupakan invers dari hasil filter. Sedangkan panel ketiga pada baris kedua merupakan pembanding hasil filter dengan citra biner sebelum difilter.

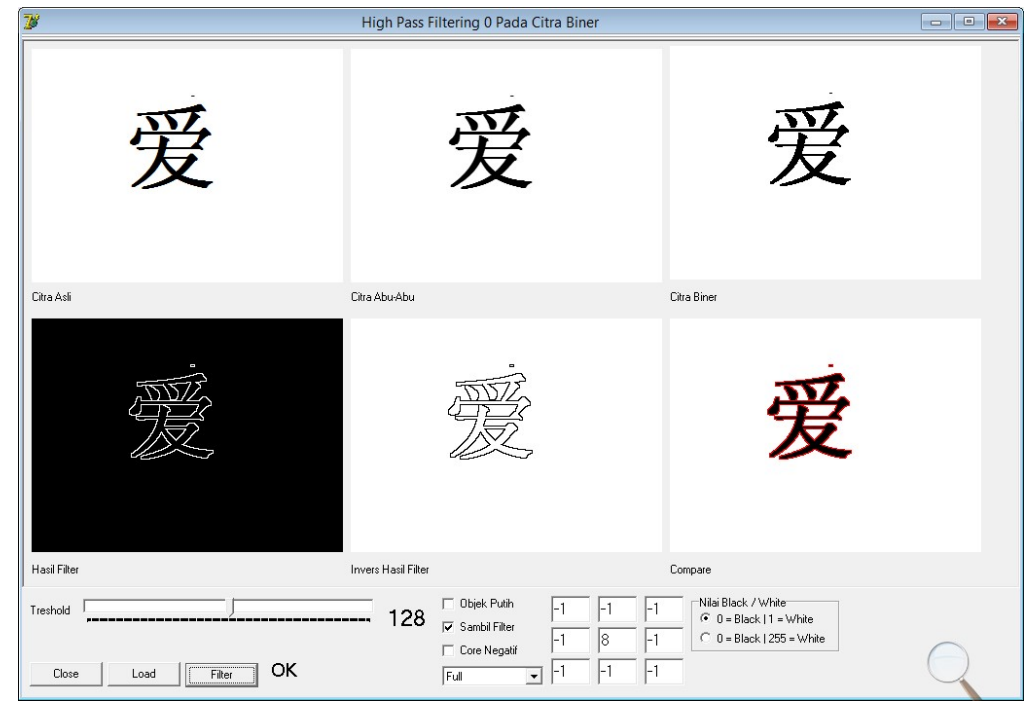

Gambar 4. Tampilan Program 
Panel gambar pembanding akan membandingkan gambar hasil filter dengan citra biner yang belum difilter. Piksel hasil filter yang sama dengan warna objek dari citra biner akan diberi warna biru, sedangkan piksel hasil filter dengan warna background dari citra biner akan diberi warna merah. Contoh hasil dari keempat variasi warna objek dengan core negatif atau positif dari filter ini dapat dilihat pada gambar 6 .

\section{HASIL DAN PEMBAHASAN}

Percobaan dilakukan pada keempat varian dari objek citra dan core filter. Tiga puluh contoh citra yang digunakan untuk uji coba berikut citra-citra hasil uji cobanya dapat dilihat pada gambar 5. Pada gambar 5 tersebut diperagakan contoh hasil citra dengan hasil deteksi tepi pada bagian luar objek dan hasil deteksi tepi pada bagian dalam objek.

Filter yang dipilih adalah filter high pass filtering dengan koefesien nol dengan nilai core 8 dan nilai tetangga -1 untuk filter dengan core positif. Untuk filter dengan core negatif, filter yang dipilih adalah filter high pass filtering dengan koefesien nol dengan nilai core -8 dan nilai tetangga 1. Karena uji coba ditujukan untuk membuktikan keempat dugaan awal nomor 1 sampai nomor 4. Contoh hasil uji coba yang lebih jelas dapat dilihat pada salah satu hasil dari contoh citra yang diuji coba berikut perbandingan hasilnya pada gambar 6 .

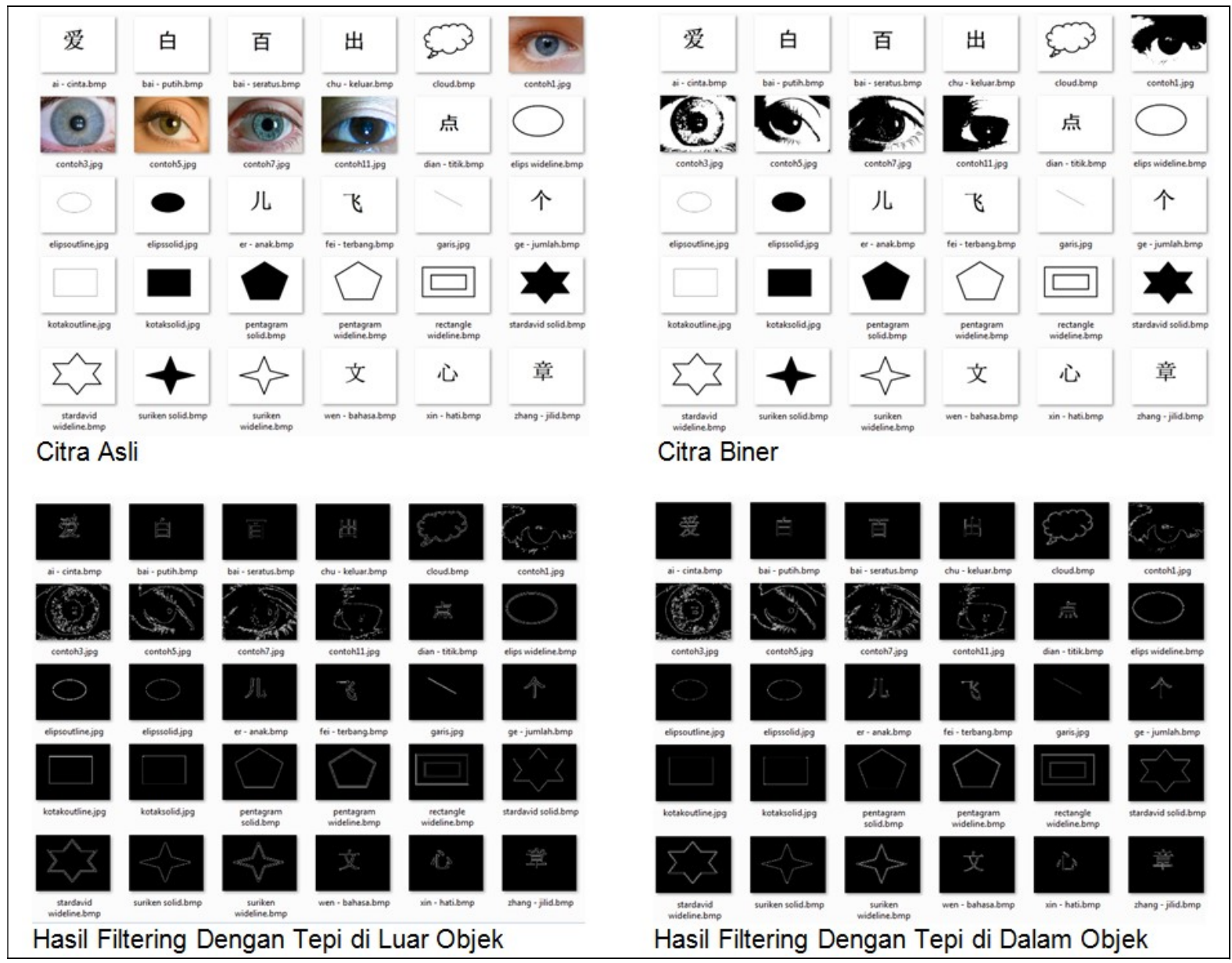

Gambar 5. Tiga Puluh Contoh Citra Dengan Hasil Filteringnya 
Gambar 5 hanya untuk memperagakan tiga puluh contoh citra yang di uji beserta hasil ujinya. Gambar 6 menunjukkan hasil uji coba salah satu citra yang lebih jelas. Pada gambar 6, gambargambar pada kolom paling kiri adalah filter-filter yang digunakan untuk melakukan filtering pada masing-masing baris. Gambar-gambar pada kolom kedua adalah citra biner yang akan difilter. Gambar-gambar pada kolom ketiga adalah citra hasil filtering. Gambar-gambar pada kolom keempat adalah perbandingan citra biner dengan citra hasil filternya. Citra yang dipilih untuk diperagakan adalah citra yang objek pada citranya memiliki tepian vertikal, horisontal maupun diagonal.

Citra di sebelah kiri merupakan citra asli. Citra di tengah adalah citra hasil filtering yang menghasilkan tepi di bagian dalam objek, dengan piksel hasil deteksi yang diberi warna biru. Citra di sebelah kanan merupakan citra hasil filtering yang menghasilkan tepi pada bagian luar dari piksel objek, dengan piksel hasil deteksi tepi yang diberi warna merah.

Baris pertama pada gambar 6 memperlihatkan ujicoba dengan objek hitam dengan filter high pass filtering yang mempunyai core positif. Citra yang dihasilkan adalah citra hasil deteksi tepi berwarna putih dengan dengan latar hitam. Pada gambar pembandingnya diperlihatkan citra hasil deteksi tepi diberi warna merah yang menunjukkan citra hasil deteksi tepi berada di bagian luar objek.

Baris kedua pada gambar 6 memperlihatkan ujicoba dengan objek putih dengan filter high pass filtering yang mempunyai core negatif. Citra yang dihasilkan adalah citra hasil deteksi tepi berwarna putih dengan dengan latar hitam. Pada gambar pembandingnya diperlihatkan citra hasil deteksi tepi diberi warna merah yang menunjukkan citra hasil deteksi tepi berada di bagian luar objek.

Baris ketiga pada gambar 6 memperlihatkan ujicoba dengan objek putih dengan filter high pass filtering yang mempunyai core positif. Citra yang dihasilkan adalah citra hasil deteksi tepi berwarna putih dengan dengan latar hitam. Pada gambar pembandingnya diperlihatkan citra hasil deteksi tepi diberi warna biru yang menunjukkan citra hasil deteksi tepi berada di bagian dalam objek.

Baris keempat pada gambar 6 memperlihatkan ujicoba dengan objek hitam dengan filter high pass filtering yang mempunyai core negatif. Citra yang dihasilkan adalah citra hasil deteksi tepi berwarna putih dengan dengan latar hitam. Pada gambar pembandingnya diperlihatkan citra hasil deteksi tepi diberi warna biru yang menunjukkan citra hasil deteksi tepi berada di bagian dalam objek.

Pada kolom ketiga diperagakan piksel yang merupakan hasil deteksi tepi, baik pada citra dengan objek hitam dengan latar putih ataupun objek putih dengan latar hitam, yang difilter dengan filter high pass filtering yang mempunyai core negatif ataupun core positif, akan menghasilkan objek dengan piksel tepi objek berwarna putih dengan piksel yang bukan tepi objek baik pada objek maupun pada latar yang berwarna hitam.

Ujicoba dilakukan pada ketigapuluh citra yang dijadikan objek ujicoba, dan semuanya atau $100 \%$ persen hasil percobaan membuktikan kebenaran dugaan awal yang sudah diajukan pada pembahasan mengenai dugaan awal di atas.

Selain pembuktian dugaan awal, didapat kenyataan bahwa piksel hasil filtering ini selalu berwarna putih dengan piksel yang bukan tepi objek berwarna hitam. Pada baris satu dan kedua terlihat objek citra hasil filtering sama besar. Pada baris ketiga dan keempat objek citra hasil filtering juga sama besar. Objek citra hasil filtering pada baris ketiga dan keempat lebih kecil dan lebih ramping daripada objek citra hasil filtering pada baris kesatu dan kedua. 


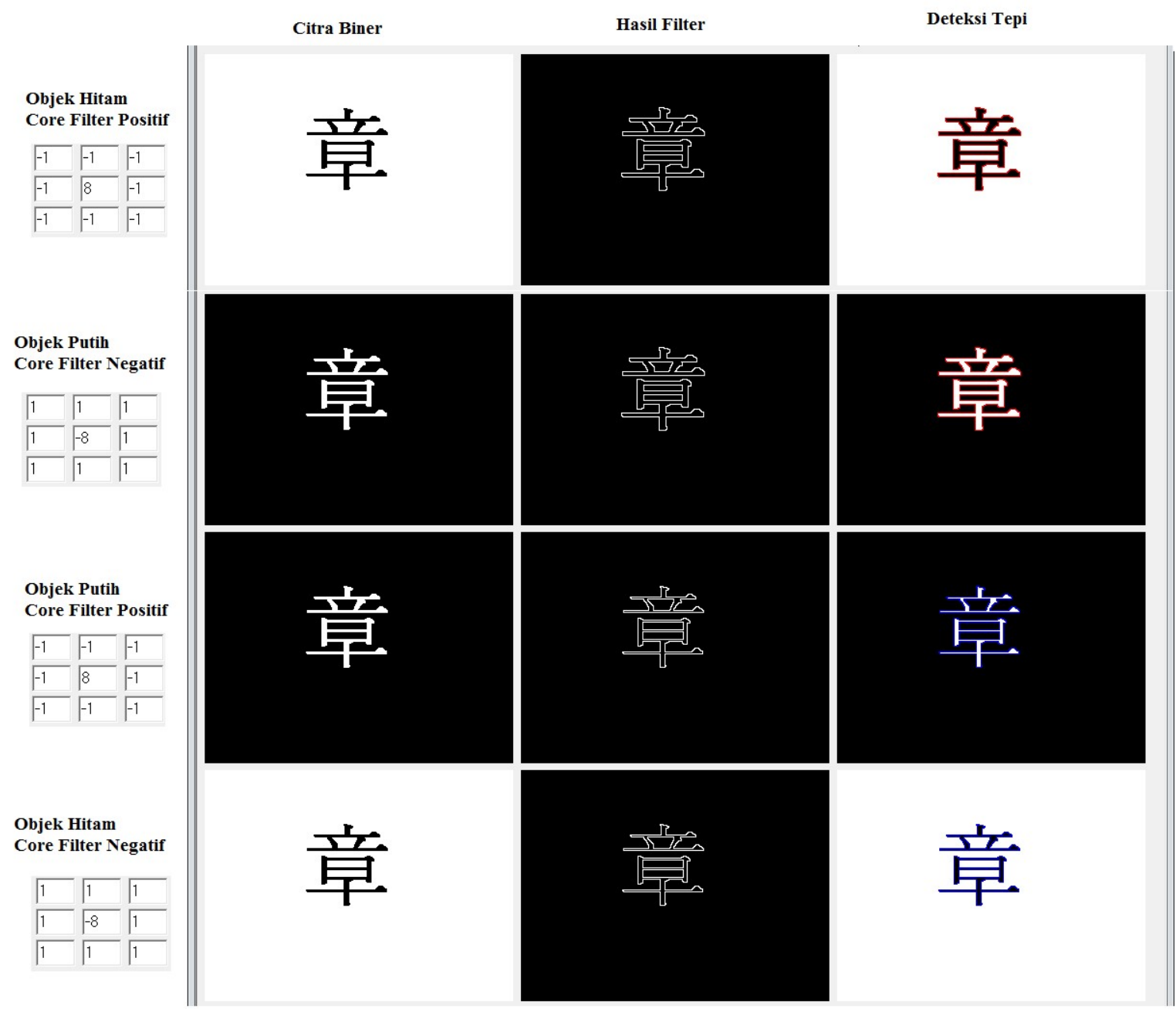

Gambar 6. Contoh Hasil Filtering

\section{KESIMPULAN DAN SARAN Kesimpulan}

1. Filter high pass filtering yang mempunyai total koefesien nol dengan core positif pada citra biner dengan objek hitam dan latar putih akan menghasilkan tepian pada bagian luar dari objek. Efek yang sama terjadi pada filter dengan core negatif, pada citra biner dengan objek putih dengan latar hitam.

2. Filter high pass filtering yang mempunyai total koefesien nol dengan core positif pada citra biner dengan objek putih dan latar hitam akan menghasilkan tepian pada bagian dalam dari objek. Efek yang sama terjadi pada filter dengan core negatif, pada citra biner dengan objek hitam dengan latar putih.

3. Semua piksel tepi yang dihasilkan dari filter high pass filtering yang mempunyai total koefesien nol dengan core negatif maupun core positif, baik pada citra biner dengan objek hitam dengan latar putih maupun citra biner dengan objek putih dengan latar hitam, akan berwarna putih, dengan semua piksel selain tepi pada objek ataupun latar berwarna hitam. 


\section{Saran}

Untuk penggunaan lebih lanjut, filtering dengan citra biner dapat dirancang untuk sebagai pengganti structuring-element sehingga dapat menghemat pemakaian logika IF dalam proses morfologi citra untuk menyederhanakan proses morfologi dengan memanfaatkan iterasi saja.

\section{Ucapan Terima Kasih (Acknowledgement)}

Terimakasih kepada Tuhan Yesus yang sudah membantu memberikan hikmat dalam penelitian, serta para pejabat struktural Universitas Bunda Mulia, Rektor UBM Bapak Doddy Surya Bajuadji, S.E., MBA., Pelaksana Harian Rektor Bapak Howard S. Giam, S.E., Ak., MBA., Ibu Kandi Sofia Senastri Dahlan, Ph.D., selaku ketua LP3M Universitas Bunda Mulia yang sudah membiayai penelitian ini beserta tim reviewernya, rekan-rekan dosen di program studi teknik informatika yang sudah memberikan saran bentuk-bentuk bangun dua dimensi yang sering muncul, serta asisten peneliti TriYatmo Noveary yang banyak membantu dalam mencatat hasil uji coba.

\section{REFERENSI}

Clausthal. O. R. Vincent., Folorunso. O., (2009), A Descriptive Algorithm for Sobel Image Edge Detection, Proceedings of Informing Science \& IT Education Conference (InSITE).

Putra. Darma., (2010), Pengolahan Citra Digital., Penerbit Andi, Yogyakarta.

Khalefa, Mustafa Salah., Amin Abduljabar, Zaid., Ameer Zeki, Huda. , (2011), Fingerprint Image Enhancement By Develop Mehtre Technique, Advanced Computing: An International Journal ( ACIJ), Vol.2, No.6, November 2011

Makandar, Aziz., Halalli, Bhagirathi., (2015), Image Enhancement Techniques using Highpass and Lowpass Filters, International Journal of Computer Applications (0975 - 8887), Volume 109 - No. 14, January 2015

Mulyana, Teady. M.S., Noveary, T. Yatmo., (2017), Pengaruh High Pass Filtering Dengan Koefesien 0 Pada Citra Biner, Laporan Penelitian, Universitas Bunda Mulia, Jakarta (Tidak dipublikasikan, dapat diakses di perpustakaan Universitas bunda mulia)

Roopashree, S., Saini, Sachin., Ranjan Singh, Rohan., Enhancement and Pre-Processing of Images Using Filtering, (2012), International Journal of Engineering and Advanced Technology (IJEAT), ISSN: 2249 - 8958, Volume-1, Issue-5, June 2012

Shareef. Zahid, Hussain. Saqib, and Darus. Maslina., (2012), Convolution operators in the geometric function theory, Journal of Inequalities and Applications, Published: 2 October 2012 (DOI: 10.1186/1029-242X-2012-213). p213

Sutoyo, T., mulyanto, E., Suhatono V., Nurhayanti OD., Wijanarto., (2009), Teori Pengolahan Digital, Andi Offset, Yogyakarta.

Umar. A., Yushau. B., Ghandi. B. M., (2007), Convolution of two series, Australian Senior Mathematics Journal Volume 21 No. 2, p:6-11 